\title{
Craft and the archive: Museum collections and memory in a Balinese village
}

\author{
Siobhan Campbell
}

\begin{abstract}
This paper examines the different forms of indigenous agency embodied in a museum collection and identifies personal relationships as a constructive platform from which to understand objects in collections of material culture. Specifically, it describes the results of a field investigation to gather Balinese responses to the Forge Collection of Balinese Art at the Australian Museum. This approach reflects the broadening vision in museum practice and scholarship over the last decades, recognising that most museum institutions describe themselves as the custodians or guardians of collections and seek to engage with the indigenous communities that produced them. Most people in the village of Kamasan in East Bali, Indonesia, have recollections of the late collector and anthropologist Anthony Forge, given that only 40 years has passed since he lived in the village with his family. This paper relates some general responses to his collecting project before considering the complex and productive relationship between Forge and the artist Mangku Mura. Not only is it apparent that the relationship between artist and anthropologistcollector had implications for the material form of art produced in the village, and subsequently housed in the museum collection, it shows that traditional artists produce their art in defiance of conventional understandings of 'traditional' art. While this paper is an occasion to reflect on the applicability of a particular field methodology and approach to other cultural collections, it also points to the wider implications for interpreting 'traditional' practices by opening up to debate ideas about timelessness and originality in the context of changing social relations.
\end{abstract}

A broadening vision in museum practice and scholarship in recent decades has
led museums around the world to re-envisage their mission as the custodians of
collections in their care. Along with this has come greater acknowledgement of
the agency of indigenous people in the process of making museum collections.
This paper describes one attempt to engage with a community of Balinese artists
in relation to a collection of Balinese paintings housed at the Australian Museum
in Sydney. Initially collected during the 1970s by the English anthropologist
Anthony Forge (1929-1991), the return of the museum 'archive' to the village of
Kamasan highlights the reciprocal ways in which relationships between artists
and anthropologists work. Given that only 40 years have passed since Forge
conducted his research in the village, most people in Kamasan still remember
the collector. Their responses generated new perspectives on the impact of
Forge's collecting and research on the people with whom he worked and on
the trajectory of Kamasan art. In addition to describing the ways that Forge is 
remembered, this paper examines collaboration in terms of the role that Forge played in the career of the artist Mangku Mura (1920-1999) and the critical role that Mangku Mura played in interpreting the art that Forge collected.

The Australian Museum houses a major collection of more than 200 Balinese paintings collected by Forge. The anthropologist, from whom the Forge Collection takes its name, became chair of the newly established Department of Prehistory and Anthropology at The Australian National University in 1974. Immediately prior to his Canberra appointment, Forge spent a year doing fieldwork in the village of Kamasan in Bali. His selection of Bali as a field site was partly motivated by a desire to extend his comparative perspective beyond the insights he had gained during previous fieldwork amongst the Abelam in New Guinea (Forge 1966, 1973). From October 1972 to September 1973 Forge purchased 104 of the paintings now in the Australian Museum collection; he made shorter fieldwork visits in 1977, 1979 and 1986. Forge purchased a combination of old paintings, some that had belonged to temples or family collections, and new works by living artists.

Although few twentieth-century anthropologists paid serious attention to material culture, Forge belongs to a small group who produced well-documented collections in the course of their research (Campbell 2014). Even though Forge was not under commission to make the initial collection, buying art was always an explicit part of his field investigations. The Australian Museum did not become involved with his collecting project until 1975, when Forge offered his collection of paintings for sale. After acquiring his initial collection, part of which was exhibited at the Australian Museum in 1978, and commissioning a further collecting trip in 1979, little interest was shown in the collection until 2009, when I was offered the chance to conduct research on the Forge Collection. ${ }^{1}$ By this time, the practice of collecting material culture by anthropologists was subject to higher levels of scrutiny than four decades ago, when Forge assembled the collection.

This is not to say that Forge was unmindful of the ethics of collecting or the implications of buying art while working in Kamasan, rather that, in today's museum environment, collection interpretative strategies are now informed by the principle of intercultural exchange. In fact, Laura Peers and Alison Brown (2003) identify attempts to engage with 'source communities' as one of the most important developments in the history of museums. ${ }^{2}$ From July 2010 April 2011 and September-December 2011 I conducted fieldwork in Kamasan to investigate local appraisals of Forge as a collector and to gather new insights about the paintings he collected. Visual material was a key component of my

1 The research was made possible with a postgraduate scholarship funded by an Australian Research Council Linkage Project between the University of Sydney and the Australian Museum, 'Understanding Balinese painting: collections, narratives, aesthetics and society'.

2 The term 'source communities' refers to: 'groups in the past when artefacts were collected, as well as to their descendants today. These terms have most often been used to refer to indigenous peoples in the Americas and the Pacific, but apply to every cultural group from whom museums have collected: local people, diaspora, and immigrant communities, religious groups, settlers, and indigenous peoples' (Peers \& Brown 2003: 2). 
research. I took photographs of all the paintings in the Forge Collection, as well as images of people and places that Forge had photographed. This methodology has been used by others to draw out stories about collector identities and collected objects. ${ }^{3}$ Formally, the process is known as visual repatriation or photoelicitation, and is described as a way to understand 'the differing perspectives and interpretations that source communities have of history and knowledge, and of their methods of narrating this information' (Dudding 2005: 218).

Following Rodney Harrison et al. (2013: 4), in the ensuing discussion this paper attempts to go 'beyond the observation that indigenous people and ethnographic objects had (and continue to have) agency' to consider the broader implications of such agency. This is preceded by a brief introduction to the visual art of Kamasan, leading to an explanation of why this kind of art has often been regarded by Western observers as belonging to the condition of craft. While such categories are not really pertinent to Kamasan understandings of art, and say more about ethnocentric bias in the minds of foreign observers, the examples cited throughout this paper show that Kamasan artists produce works with unique characteristics and individual histories of articulation. While these qualities might support the contention that paintings fit a category of fine art, there is considerable scope to rethink how notions of skill and individuality are conceived in relation to the way Balinese artists work.

\section{Kamasan art}

Most of the paintings Forge collected come from Kamasan, a village located between the east coast and the mountain ranges of Gunung Agung on the island of Bali. This area of Bali is something of a backwater compared to the urban sprawl characterising the south of the island, yet Kamasan has a central place in Balinese history. Historically, Kamasan was home to communities of artisans working in the service of the pre-colonial rulers of Bali, the most preeminent of whom was based in nearby Gelgel and later Klungkung. Kamasan village itself is divided into wards (banjar) reflecting the specialised services provided by members of the commoner castes to the ruling court as goldsmiths (pande mas), smiths (pande) and painters (sangging).

Kamasan paintings are produced to be displayed in temples and on ritual occasions. Even when produced for different spaces and contexts, paintings generally comply with standard formats. Firstly, flags are produced in pairs with the same image on both sides, so a pair of flags consists of four pieces of painted cloth. Secondly, there are narrow-strip paintings (ider-ider) which hang around the eaves of pavilions (bale), and shrines (gedong), and may be

3 For instance, Haidy Geismar and Anita Herle conducted a particularly evocative study of a historical collection of photographs from Vanuatu. Their work explored 'the resonance of photographic images' in communities; they also related the photographs to the intellectual history of anthropology as an academic discipline and to the social history of anthropology as a crosscultural enterprise (2009: 3). 
up to 15 metres in length. The narratives depicted on ider-ider are viewed by moving along the painting from right to left, sometimes in reverse order, or in complex combinations of these. The third type are rectangular (langse), which are hung as curtains to screen offering platforms. They often have lengths of imported printed fabric sewn along the bottom and Chinese coins with holes in the middle (kepeng) attached to the top edge. Fourthly, there are roughly square cloths (tabing), which are most often hung over the wooden backboards of offering platforms. The narrative on the latter two types of cloth is divided into scenes. These scenes might be even rows of a standard width, or one large and several smaller scenes. Different calendars, including the 35-day calendar (palelintangan) and the earthquake calendar (palindon), are produced in the same format. Cloths are also made for ceiling spaces (lelangit) to provide cosmic orientation (pangideran) in the context of certain rituals.

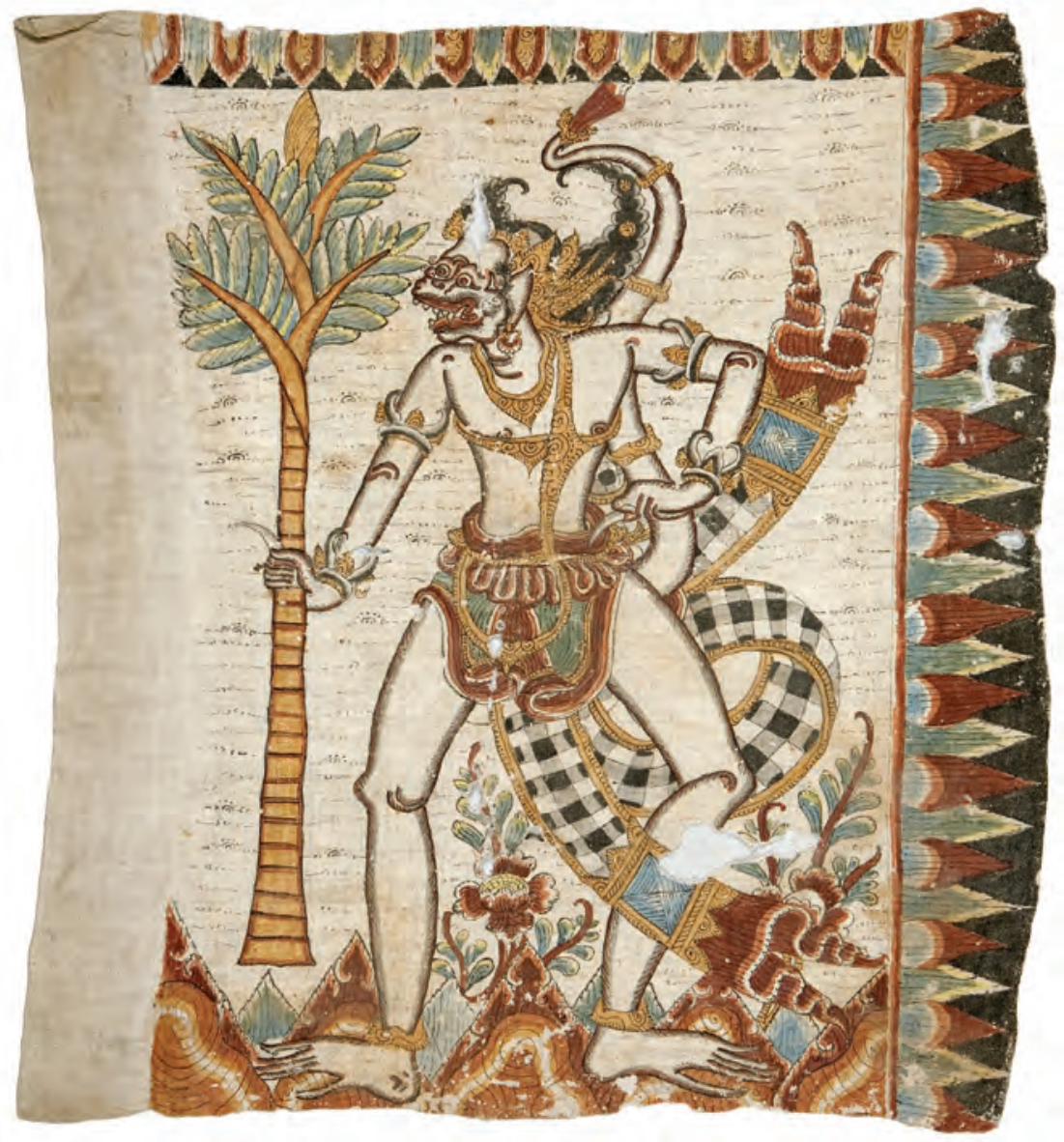

Figure 1. Unknown artist, Hanoman, c. 1900, kober, natural pigment on cotton cloth, 490 x 530 mm, Forge Collection E074236

Photo: Emma Furno, courtesy of the Australian Museum 
Kamasan art is narrative in that paintings depict versions of stories and myths found in written, oral and performance genres. Kamasan art is closely related to shadow puppet (wayang) theatre and painted figures are depicted in almost the same manner as flat Balinese shadow puppets except in three-quarter view. The stories come from epics of Indian and indigenous origin, relating the lives of deities, the royal courts and sometimes commoner families. These narratives serve a didactic and devotional function and the stories acquire many layers of meaning in the context of their display. They are intended to gratify and entertain the gods during their visits to the temple, as well as the human participants in ritual activities.

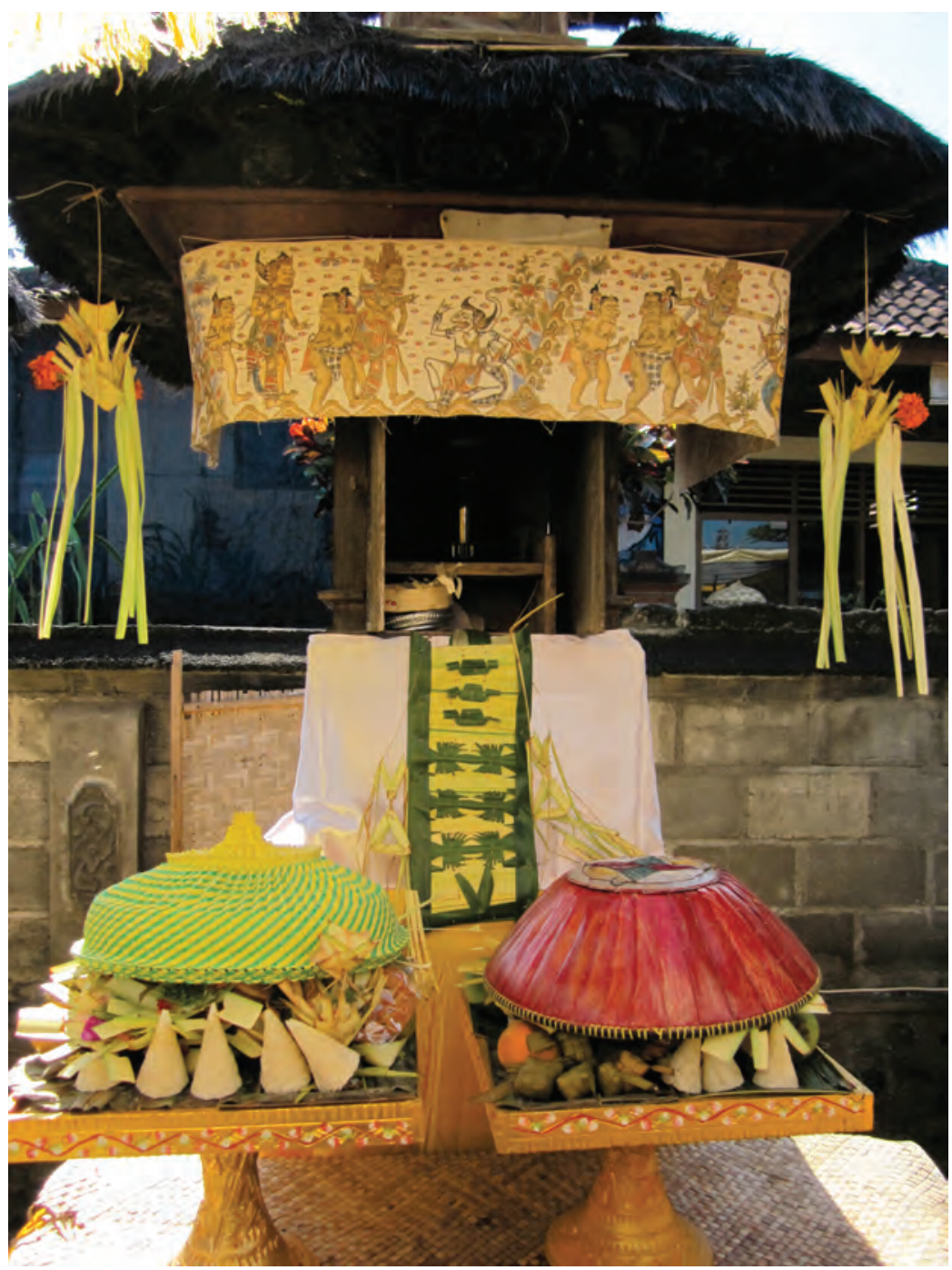

Figure 2. Ider-ider on temple shrine in Pura Kawitan Pasek Gelgel, Kamasan, 2010 Photo: Siobhan Campbell 
When displayed in temples and family compounds, paintings are hung only for the duration of festivals or ceremonies. At other times they are folded, or rolled, and stored alongside other ceremonial equipment. Paintings are normally produced on cloth (kain belacu) made from cotton grown on the island of Nusa Penida or imported from Europe. They are also painted on bark cloth (daluwang) sourced from around the archipelago and on wooden boards or panels (parba) that form the back of bed-like offering platforms (taban).

Paintings were once found in temples and royal courts throughout Bali and, until the early twentieth century, several villages around Bali practiced a similar style of painting. Today this art continues to be produced by small numbers of artists in other Balinese villages; however, Kamasan is the only village where this style predominates. The most important distinction between Kamasan and the other visual art traditions of Bali is that the style of Kamasan has not been superseded by newer styles that took root in other Balinese villages (see Vickers 2012). There is a tendency to describe these distinctions in terms of the conventional craft and art divide. Certainly, some aspects of this 'traditional' painting context have seen Western observers relegate Kamasan painting to the condition of craft, regarding its makers as artisans rather than artists (Cooper 2005: 5). This legacy dates back to at least the 1930s, when resident Western artists described Kamasan art as repetitive, imitative and lacking originality and thus of little aesthetic distinction. The subjectivity of such categories is apparent in their criticism of Balinese artists for their failure to depict everyday life while admiring their technical virtuosity (Covarrubias 1937).

The Forge Collection was assembled at a time when at least some visual anthropologists, including Forge, were questioning this interpretive frame. Forge recognised that this tradition was not subject to cultural decline, but rather, to ongoing rearticulation. In particular, he wanted to demonstrate how paintings could be regarded as original in the context of their collectivities, explaining why he focused on the work of individual artists. In the contexts of viewing Forge's photographs that I took to Kamasan, the families of artists also confirmed the significance of particular artists within their family histories when they picked out photographs that they wanted to reproduce and keep for themselves, a process that Haidy Geismar (2009: 292) refers to as 'taking images back'. The photographs not only enacted tangible connections with the past, enlarging and displaying them transformed the photographs into statements of prestige. By reclaiming photographs of artists in their family histories, people asserted the agency of their own kin groups in the art history of the village, emphasising the high value placed on locating oneself within a lineage of accomplished artists. These acts might be taken to problematise the notion that this tradition is without an art historical trajectory. 


\section{The Forge Collection revisited}

Attempts to revisit Forge's work would have been decidedly different if not for the fact that so few people have left Kamasan. Even though most of Forge's key collaborators are no longer alive, their descendants live in the same house compounds. Superficially and despite cosmetic changes, such as asphalt roads, temples having been refurbished in dark grey andesite, and extensions to family compounds, the layout of the village has changed little in 40 years. Families have remained where Forge left them and even family members who have migrated to urban centres for work, or married into other villages, regularly return to Kamasan.

In my initial introductions to people in the village it was quickly established that there was no need to explain who Forge was. It seemed that everyone I spoke to knew of 'Tuan (mister) Anthony', a somewhat archaic term of address for foreign males that was used almost exclusively for addressing Europeans from the colonial period until the 1990s. His imposing physical form and smoky cigars made a big impression on children; however, the most popular story related to Forge is about his flight into the village by helicopter. This incident took place during the filming of a BBC television series Face values in 1977 and elevated Forge to legendary status in Kamasan eyes. Even people who were too young to have witnessed the spectacle had heard of Tuan Anthony landing the helicopter. People talked of running from their homes to watch the powerful beast descend; the wind from the propellers mowing down the coconut trees planted around the perimeter of the field in its wake.

Recollections of the larger-than-life figure extend to the Forge Collection too. Many people commented that Forge assembled the biggest collection of Kamasan art; this impression is probably related to the visibility of his collecting activities as well as to the circulation of the catalogue in the village. People witnessed the collection grow in size over a period of months and were well-informed about what he was doing. Forge's own field notes relate that, shortly after his arrival in the village, he attracted a regular stream of callers offering paintings and other old wares. They usually waited outside his house in the early morning or called by in the evening. Some of these people were established traders; however, the majority were female residents of the village, acting as agents for the owners of paintings or temple communities. Sometimes Forge purchased on the spot, but in many instances negotiations extended over several days.

Today the women of Kamasan describe how they went around nearby villages to locate paintings to sell, from which they generated income by commission. Much of the day-to-day talk about Forge was predicated around discussions of these sales. Their stories reveal that the monetary value of paintings is not determined solely by the material form of objects, there is an arbitrary component based on the intended function of the painting as well as the means of the person buying it. These distinctions were famously described by Arjun Appadurai (1986) as the 'regimes of value' in which objects circulate. Ni Wayan 
Kartini, who sold one painting to Forge, had no recollection of the narrative subject of the painting. Her strongest recollection of the transaction was that it had been a well-compensated one. Although she failed to recall the rupiah figure, Ni Wayan Kartini said that the currency value was low and that paintings were inexpensive, pointing out that although the amount would seem like nothing in today's terms, the profit was enough to purchase rice to feed her young children for several months.

As the latter remark suggests, there was no intimation that Forge was unfair in his dealings, or in the prices he paid for paintings. His residence in the village, however, took place following a period that Forge himself described as 'unmitigated disaster' (1980: 228). By this he was referring to the statesponsored purge of alleged supporters of the Indonesian Communist Party (PKI) from late 1965. During this period, murders were often perpetrated by fellow members of the same ward and, in the years following the violence, these families continued to live side by side. Local conditions thus gave rise to a situation that senior artist Nyoman Mandra said was opportune (untung). Nyoman Mandra suggested that Forge was only able to assemble such a vast collection because people needed money and were willing to sell paintings.

In Bali during the 1970s increased tourist numbers, coupled with decreasing reliance on the agricultural sector, also resulted in greater prosperity in some parts of Bali and more lucrative opportunities for artists to sell their work. Most people in Kamasan describe the last two decades of the twentieth century as the most profitable years of their art industry. These years came to an end in 2002 when bombings reduced visitors to a trickle. ${ }^{4}$ According to this locally defined timeline, Forge was the earliest collector in recent history and it is generally held that his collecting project stimulated the village art industry in the years following. Although Forge was certainly not the first foreigner to visit Kamasan and collect art - community memories extend back to the 1930s when foreign artists went to the village - this goes some way towards explaining why he is remembered as an exemplary collector. Forge's presence in the village is equated with steadily improving fortunes.

This also partially explains why Forge's removal of the paintings from Kamasan did not elicit remarks about cultural loss. Although stories lamented the fact that Bali's manuscript literature (Iontar) was removed by the Dutch colonial authorities, people did not envisage Forge's collecting project along similar lines of cultural appropriation. Many people became sentimental when looking through images of the Forge Collection, regretting that they no longer had old paintings in their families. These feelings, however, were tempered by a sense of pride that their art was collected and displayed overseas. People also commented

4 A series of bomb attacks in tourist resort areas of South Bali in 2002 and 2005 resulted in hundreds of human casualties and a major economic downturn impacting thousands of people who were directly and indirectly employed in the tourist economy. The events also gave rise to a kind of cultural crisis, often discussed in the context of the Ajeg Bali movement. This movement debated the position of Bali within the Indonesian nation state and questioned the flow of immigrants from other parts of Indonesia into Bali (see Schulte Nordholt 2007, MacRae 2010). 
that foreign museums were better placed to take care of their paintings, an insight heightened by their experiences of storing old paintings. Many times when a painting was brought out from under a bed or cupboard, new evidence of rodent or insect activity were revealed. Comments about Forge as a collector were also made in the context of recurrent media reports about the theft of sacred objects from temples around the island (see McGowan 2008; HauserSchäublin 2012). Media coverage tended to stress the role of the international art market in motivating the thefts, though the conversations I heard amongst Kamasan residents seemed to hold the Balinese collaborators who knowingly removed objects from temples in greater contempt. ${ }^{5}$

To balance the generally convivial and positive evaluations of Forge, I now turn to the transgressions held against him. This is not to claim that people openly criticised him, rather to acknowledge that his collecting project gave rise to certain resentments. Frictions are to be expected in the conduct of any fieldwork, but are probably heightened when fieldwork involves buying art. In Forge's case they were largely the result of his close affiliation with artist Mangku Mura. This relationship has important implications for understanding how a particular individual was involved in the making of the Forge Collection. The following discussion covers two main points. After providing some brief background details about the artist Mangku Mura, I explore a painting he produced for the Forge Collection in some detail so as to explain why the painting might be taken to embody the mutual interests of artist and anthropologist. Secondly, I discuss how Mangku Mura's agency is expressed in subsequent interpretations of the collection by describing his involvement with an old painting that Forge collected.

\section{Mangku Mura}

When Forge arrived in Kamasan, the 50-year-old Mangku Mura was well established as a painter and went on to become one of the most successful Kamasan artists of his generation. His work was widely collected in Bali, as well as by museum institutions and collectors internationally. Despite outside recognition, within Kamasan, Mangku Mura is perceived as an outsider because, unlike most Kamasan artists, he was not born into a family of painting descent. By the time he took up painting he had completed primary school and was working alongside his parents as a sharecropper. Initially he apprenticed himself to one artist and, once he had learnt how to draw (ngreka), he began to earn money to support himself. He then moved on to new teachers and spent time learning alongside several key artists. This unusual system of learning led him to appropriate different elements from each teacher and is believed to account for his idiosyncratic style. As a young man Mangku Mura also studied to become a lay priest (pamangku).

5 Cases reported in the press include Bali Post (19 September 2010) and the Jakarta Globe (8 September 2010). 


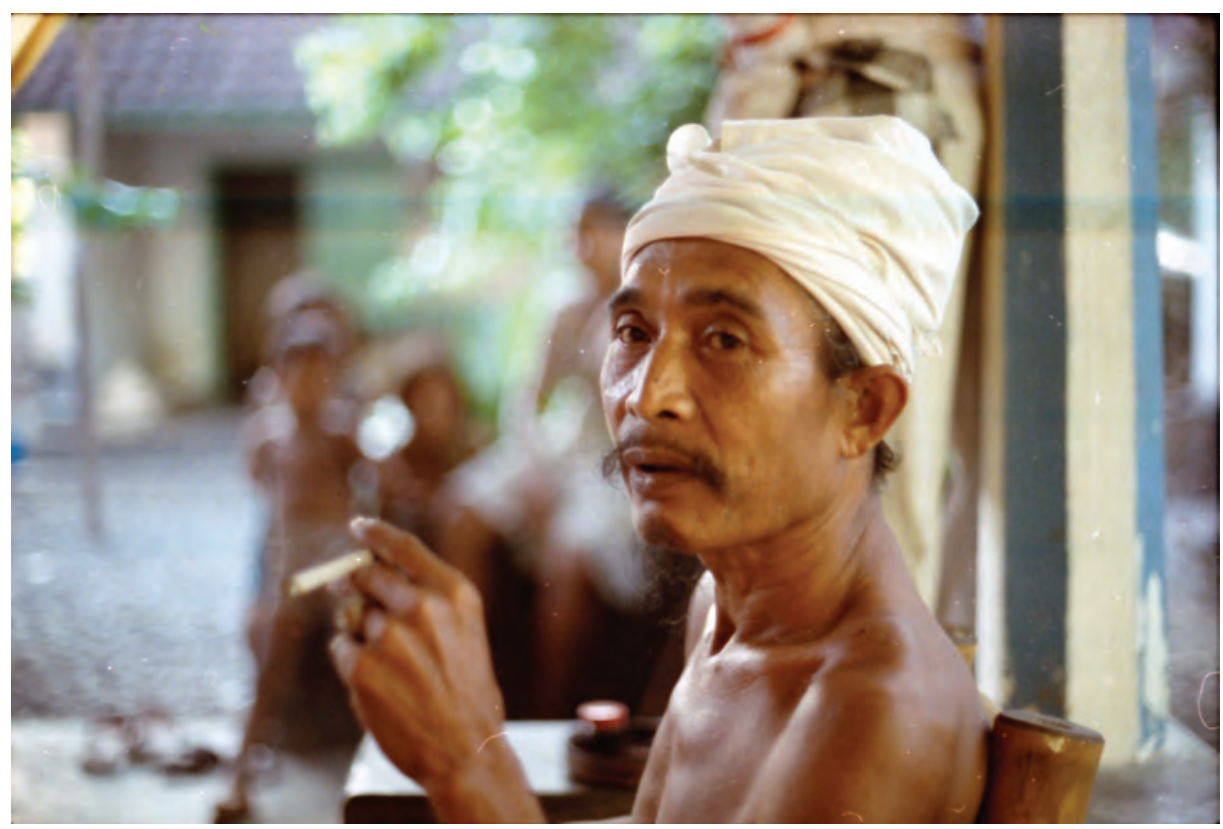

Figure 3. Artist Mangku Mura, 1977

Photo: Anthony Forge, courtesy of the Australian Museum

To this day, people in Kamasan attribute a share of Mangku Mura's success to Forge. Forge was aware that his dependence on Mangku Mura was controversial, however, Mangku Mura's inherent capacity and willingness to talk about paintings made him an indispensable collaborator. Forge's methodological approach to studying art was premised on the notion that talking to and observing artists at work was more important than analysing the formal elements of paintings. Forge's financial support and confidence in the artist presented the opportunity and the means for Mangku Mura to pursue an extensive range of narrative work. The painting Sukrasena is a case in point. On the one hand the painting can be taken as a measure of the complex intercultural understanding between Mangku Mura and Forge. At the same time the painting reveals a lot about how artists work within a given tradition. This narrative had never been the subject of a Kamasan painting, yet, while he created something new, Mangku Mura also drew on narrative plots and allusions to a corpus of stories that were familiar to many Balinese viewers.

Mangku Mura was a brilliant storyteller. Many visual artists draw analogies between their role as storytellers and that of puppeteers (dalang) and, while the following elaboration only hints at the parallels between Balinese visual and performing arts genres, at the outset it should be emphasised that artists like Mangku Mura do not regard paintings as inanimate. His words have the capacity to bring the painting to life. When Mangku Mura completed this painting, Forge made an audio recording of him narrating the story scene by scene. The 
recording was transcribed in Balinese, and then translated into Indonesian by Forge's research assistant, Ida Bagus Wijana Purnama. The description given here is based on my translation of the transcription. ${ }^{6}$

\section{Sukrasena}

The painting is a 17-metre long ider-ider produced on three separate pieces of cloth. The story, progressing in scenes from left to right, begins with a story that is common to the painting tradition, in which the god Siwa devises a plan to test the faithfulness of his wife Giri Putri. In fact, Mangku Mura depicted the same story of Siwa and Giri Putri as part of his painting The story of Kala (Forge 1978: 30). The key points of this story are that Siwa feigns illness and, informing Giri Putri that only the fresh milk of a cow will cure him, sends her down to earth to procure the milk. On earth, Giri Putri meets a boy herding a cow, actually Siwa in disguise, and obtains the milk on the condition that she makes love to him. She returns to heaven and Siwa drinks the milk. He instructs his son Gana to ask his mother how she obtained the milk. Giri Putri is trapped into lying and caught out by Gana, using a chronicle (tenung) recorded on a palm leaf manuscript to foretell the past and future. Furious, Giri Putri grabs the chronicle and throws it into a fire. Gana is only able to retrieve fragments, which explains why the chronicles in Bali no longer consistently predict the future.

In most conventional narratives Giri Putri is banished from heaven to earth and takes the form of Durga, the goddess of the temple associated with death and decay (pura dalem). In this painting Giri Putri takes the form of a pig. The next scene takes place on earth as the king of Tulembang embarks on a journey through the forest with his retainers. Coming upon a coconut tree, they pick the fruit and drink the milk. One of the coconut shells is cut in half and the king urinates into it, declaring that whoever consumes the liquid will fall pregnant. Siwa has descended from heaven and witnesses the vow; his spirit enters the urine of the king. When a thirsty Giri Putri arrives on earth as a pig in the next scene, she drinks the liquid in the coconut shell and gives birth to a baby girl called Rare Cili. Meanwhile, the supreme power Sanghyang Licin punishes Siwa for the unreasonable tests he set for Giri Putri and Siwa too is banished to earth in the form of a black dog.

6 In this sense my description is too reductive to adequately reflect Mangku Mura's mode of storytelling as I have been forced to omit many tangential stories and to convey the relevant details as succinctly as possible. 


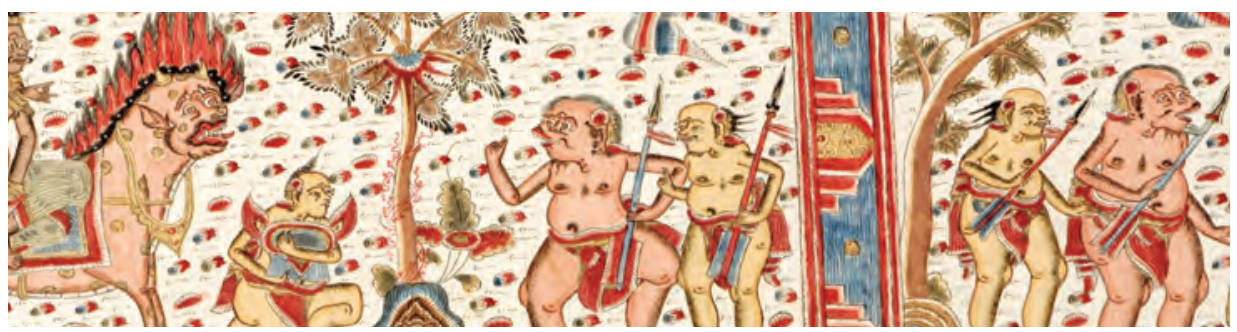

Figure 4. Mangku Mura, Sukrasena (detail 1), natural and acrylic pigment on cotton cloth, 300 x 17050 mm, Forge Collection E0742221-23

Photo: Emma Furno, courtesy of the Australian Museum

At this point the now mature Rare Cili is working at her weaving loom when it falls into the garden below. She declares that she will marry whoever retrieves the loom. The black dog, which is of course Siwa, fetches the loom in his mouth. Rare Cili has no choice but to fulfil her oath and marry the dog. She soon falls pregnant and gives birth to a boy called Sukrasena. As Sukrasena grows older he incessantly asks his mother about the identity of his father. Rare Cili tells him to cease asking about his father, but advises him to take her black dog to help protect his crops. When Sukrasena spots a sow amongst his crops he orders the dog to chase it away. The seemingly useless dog approaches the sow but does nothing; Sukrasena becomes so enraged that he withdraws his dagger (kris) and kills the dog and the pig. Returning home to inform his mother, Rare Cili admonishes him for his lack of compassion and tells him that the dog was his father and the sow his grandmother. Sukrasena weeps in sadness and withdraws his weapon, intending to kill his mother, when Siwa appears.

The murder has released Siwa and Giri Putri from their animal forms. Now Siwa appears on earth in the form of an elderly ascetic and orders Sukrasena not to kill his mother. He grants Sukrasena protection and tells him to visit the king Prabu Dadah in Tulembang. Siwa says he should first take a heavenly nymph called Luhtama as his wife. This part of the narrative is based on the story known as Rajapala. Sukrasena departs for the garden of Sumbrewijaya in search of his chosen wife and sees the nymphs descend from heaven to bathe in a pool. While they are bathing he hides Luhtama's scarf, which is her means of flight. Left behind when the others fly back to heaven, she marries Sukrasena and shortly after gives birth to a son called Jaya. Not long after Luhtama falls pregnant again.

The elderly ascetic (Siwa) reminds Sukrasena to depart for the palace of the King of Tulembang. On arriving, Sukrasena reports to a chief minister, claiming that Prabu Dadah is his grandfather. The minister almost beats Sukrasena to death before the king intervenes. Sukrasena relates the events that followed from the king's journey through the forest when he urinated in the coconut shell. Realising that Sukrasena is indeed his grandson, the king resolves to place him on the throne and Sukrasena takes leave to collect his family. In his absence Luhtama has given birth to a second son called Sura and, having fulfilled the promise she 
made when he captured her, asks Sukrasena to permit her to return to heaven. Despite telling her that he is to be crowned king of Tulembang, Sukrasena fails to convince her to stay and becomes so angry that he unwittingly kills their youngest son when he throws him on the ground. Left alone with his eldest child, Sukrasena combines the names of both sons. On their way to meet with the king, Sukrasena tells Jayasura that, as he is now to be appointed king, he will no longer be of the commoner (sudra) caste, therefore he should not be addressed as father (bapa) in low Balinese but as father (ajung) in high Balinese. The painting concludes with Sukrasena's arrival at the palace. Upon ascension to the throne he is released of his low-caste status and becomes a noble (gusti).

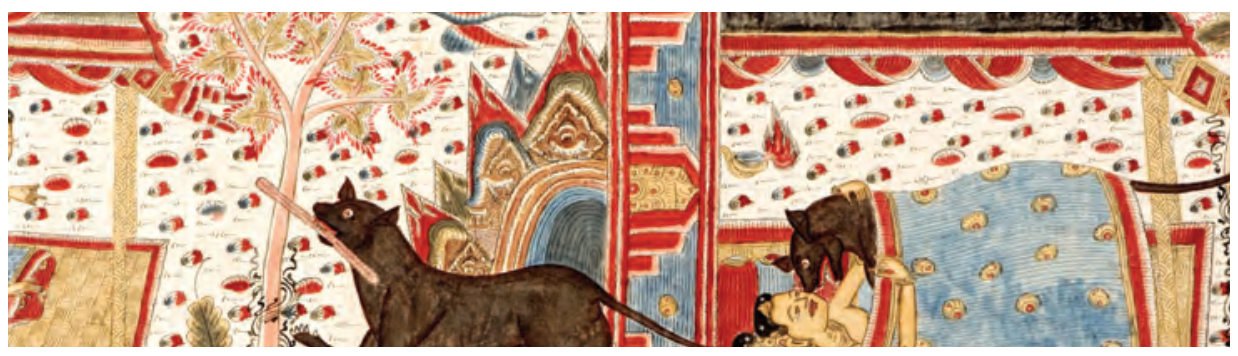

Figure 5. Mangku Mura, Sukrasena (detail 2), natural and acrylic pigment on cotton cloth, 300 x 17050 mm, Forge Collection E0742221-23

Photo: Emma Furno, courtesy of the Australian Museum

Mangku Mura concluded his oral retelling of the story by saying that the painting was about 'how Sukrasena became the king of Tulembang and the story by which Muslim people all over the world describe their origins. ${ }^{77}$ What may be taken as a somewhat perplexing conclusion can be explained with reference to further contextual information about the circumstances of the commission.

In the first instance it was Mangku Mura who persuaded Forge to commission him to paint this story. The artist was inspired by a drama performance that had taken place in the village some weeks earlier. Although Forge, who had not seen the performance, agreed to the commission, he was concerned that the story was 'contentious and potentially defamatory' (Field Diary, 17 June 1973). Mangku Nengah Latra, Mangku Mura's eldest son, was a young member of the drama group and he explained that the objective of the performance was to inform the predominantly Balinese Hindu audience why Muslims do not consume pork and dislike keeping dogs. From the perspective of Kamasan residents, the latter restrictions are pertinent as their neighbours in the customary village of Gelgel include a community of Balinese Muslims. This community is believed to be descended from the retinue of Javanese retainers who arrived in Bali in the sixteenth century with the establishment of the Gelgel court. Their mosque, the oldest in Bali, stands in close proximity to the Hindu state temple (pura dasar).

7 Mangku Mura stated in Balinese: mangden presida sami uning ring paundukan wantah penyeneng ring tulambeng ngentosin prabu dadah sampunika kawastanin sukrasena cerita puniki ketuluh antak agama islam masumi sane nganggen unduke rauh mangkin anggene ring seluruh dunia puniki. 
Despite ostensibly being about the origins of Islam, Mangku Mura's narrative was related in the same manner as Hindu stories of creation and it fits narrative patterns familiar to Balinese artists. Mangku Mura told his children that in the mid-1950s, when he left his young family and went to the island of Nusa Penida in search of work, he stayed alongside Muslim villagers and studied traditional healing and treatments which involved the recitation of Arabic mantras. The duration of his visit to Nusa Penida is not clear, yet it was evidently an important episode in the life story he recounted to his family. It explains why they believe he was familiar with systems of Islamic belief.

More generally, Islam is not necessarily an alien doctrine to Balinese people. It is found in religious texts of the nineteenth century and there is a painting in the Forge Collection depicting a story with Islamic origins known as Menak (see Vickers 2005: 301-03). The Sukrasena shares features with the Kebo Mundar story related in Balinese manuscripts and paintings; this story relates that the first person to bring Islam to the island of Lombok was descended from a pig and has a dog convert communities through trickery (Vickers 1987: 48). Mangku Mura, however, did not pointedly identify the figure of Sukrasena as Muslim, nor does Sukrasena attempt to convert anybody, although he did engage in an act of trickery in finding a wife.

The major narrative sequence of the Sukrasena is the story of a commoner overcoming tribulations to be revealed as the rightful royal heir, a relatively common theme in other Balinese stories (Cooper 1997). In the painting the ascent to the throne by a commoner is not only sanctioned by divine powers, it is orchestrated by the deities. Mangku Mura's engagement with issues of hierarchy in the painting fits more generally with Forge's theoretical perspectives on Kamasan art. This is what Forge had in mind when he described artists who appeared to accept the established hierarchy of Balinese society, yet undermined or mocked it in their paintings (Forge 1978). In this sense we might also understand that the painting refers to entrenched hierarchies amongst commoner artists in the village. As mentioned above, Mangku Mura was considered to exist outside the official lineage of village painters, yet he was able to circumvent this hierarchy through the patronage of foreign collectors like Forge. Through this patronage Mangku Mura was able to take his art practice into new domains.

For our purposes the Sukrasena makes clear the reciprocal ways in which relationships between artists and anthropologists work. This narrative was one that Mangku Mura felt was important to paint, a request to which Forge acceded, even though it is clear that Forge did not share his enthusiasm. The Sukrasena stands out as an important painting for demonstrating how artists develop new narratives, and thus make changes within an artistic tradition, yet it was not included in either the Australian Museum exhibition of the Forge Collection in 1978 or in the exhibition catalogue. In one sense Forge was able to momentarily disregard the contentious painting, but reviewing the collection brought Mangku Mura's enthusiasm back to the fore. 
There are many ways in which the personal relationship between Mangku Mura and Forge is embodied in the Forge Collection. The example below explores their relationship in terms of the interpretation of an old painting and the museum catalogue. One of the most treasured and expensive paintings that Forge acquired in Kamasan was an old work for which he lacked any contextual information about the narrative depicted. Significantly though, in terms of subsequent interpretations, the painting was reproduced in the Australian Museum catalogue (Forge 1978). Mangku Mura reacquainted himself with the old story depicted in the painting and reintroduced the narrative into religious ceremony.

\section{The Australian Museum catalogue}

In general terms, people in Kamasan believe that the catalogue generated renewed interest in their village and played a role in promoting Kamasan art to the world. The catalogue also had an impact on the paintings they produced. Similar circumstances have been observed in other Indonesian contexts, where traditional artists have access to catalogues from overseas exhibitions. For instance, Jill Forshee (2001: 61) describes textile producers in Sumba copying motifs from older Sumbanese textiles illustrated in exhibition catalogues and incorporating the motifs in new cloths. Andrew Causey (2003: 156) also talks of catalogues as the 'greatest exposure to traditional forms' among Toba Batak wood carvers, and explains how they are used to reproduce and replicate artefacts.

Kamasan artists continue to refer to Forge's catalogue, though many use wellthumbed black and white photocopy reproductions of the original. Even if the close relationship between Mangku Mura and Forge had gone unnoticed during fieldwork, the catalogue leaves no doubt as to the nature of their collaboration. Statements and responses collected from Mangku Mura resound through the text, describing how the artist was 'persuaded' to undertake certain commissions, what Mangku Mura 'said' and how he 'described' things. More than that, the catalogue contains photographs of the artist and various family members, as well as his paintings and sketches. Since few people commented on the catalogue text, in evaluating how the catalogue was received in the village it is more pertinent to think about the visual presentation. By virtue of the catalogue, Mangku Mura's renderings of popular stories have circulated within the village. In particular, the publication of one old painting resulted in the circulation of a new narrative amongst artists. 


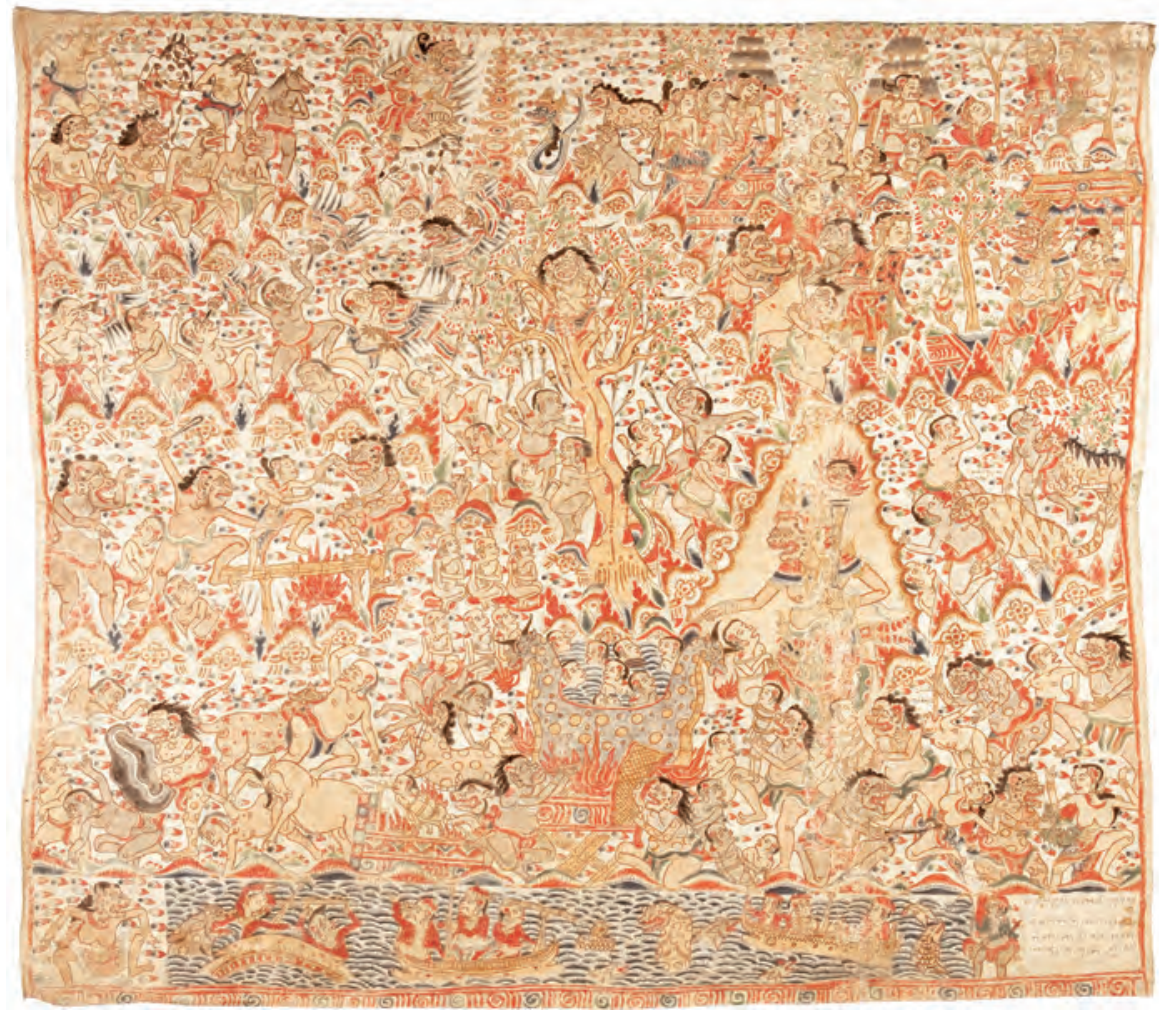

Figure 6. Unknown artist, Jaratkaru, natural pigment on cotton cloth, $1500 \times 1600 \mathrm{~mm}$, Forge Collection E074161

Photo: Emma Furno, courtesy of the Australian Museum

As mentioned above, Jaratkaru was amongst the most expensive paintings that Forge acquired. Purchased from the couple Pan and Men Soka, Forge underscored the high value of the painting by noting that the vendors intended to use the proceeds towards the purchase of a motorbike (Field Diary, 21 May 1973). It was unusual for Forge to pay such a high price given that there was no contextual information about the painting or the narrative depicted on it.

The painting in question had various scenes of punishment on it similar to those found in the well-known story of Bima Swarga, relating Bima's mission to the afterlife to rescue the souls of his step-parents. Despite consulting with several artists Forge had no success in identifying the narrative. There was also an inscription written in Balinese script (aksara) on the bottom right-hand corner of the painting, stating that the scene was painted from a manuscript (lontar) and giving a date equivalent to 1303 Saka (1381 AD). Naturally, Forge concluded that this could not possibly have been the completion date for the mid-nineteenth century painting. He explained these unresolved issues in the catalogue, writing, 'it has so far proved impossible to identify which particular story this is' or 'any particular artist who had painted it' (1978: 42-43). 


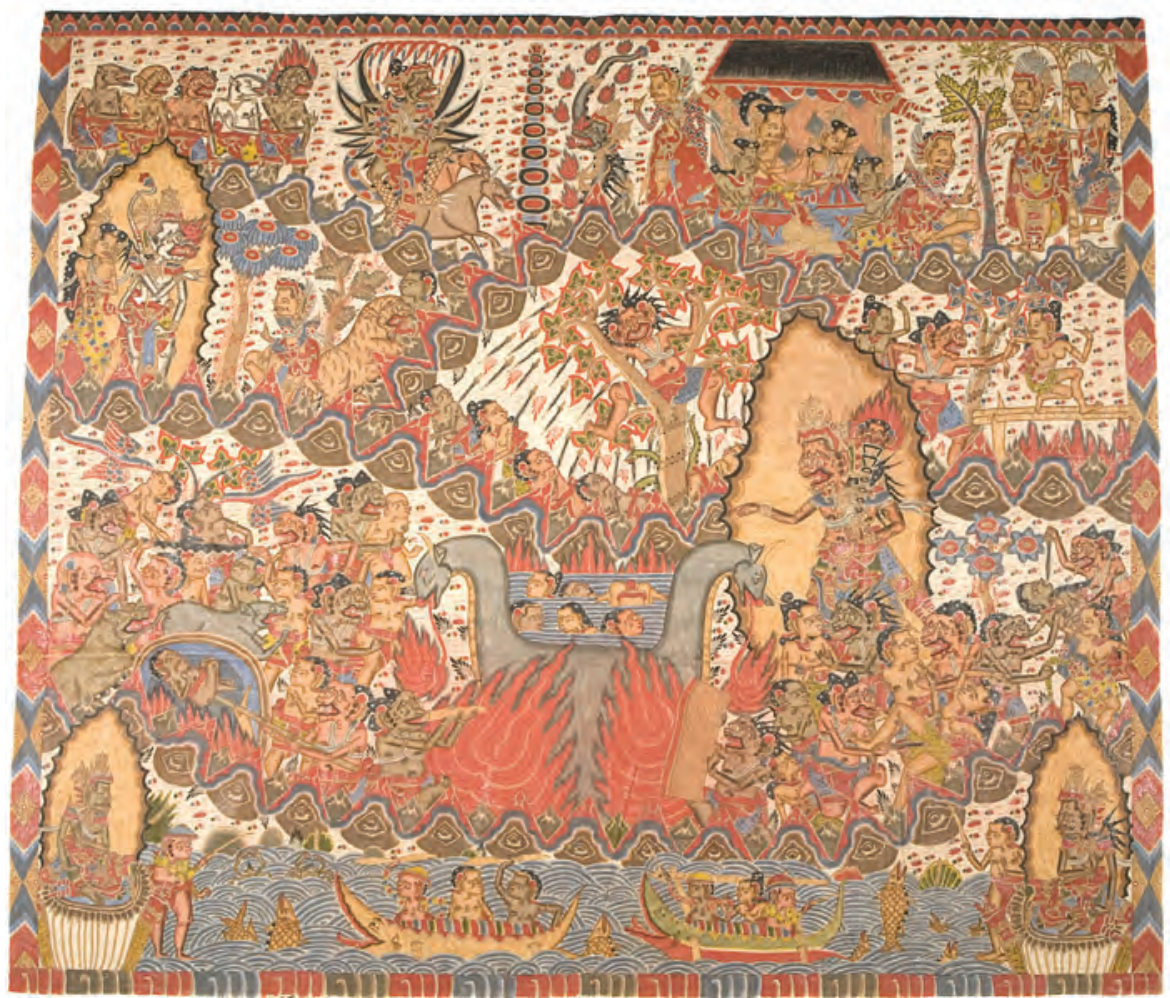

Figure 7. Mangku Mura, Jaratkaru, natural pigment on cotton cloth, 1350 x $1550 \mathrm{~mm}$, Forge Collection E076405

Photo: Emma Furno, courtesy of the Australian Museum

Ultimately Mangku Mura successfully resolved the narrative ambiguity. When Forge went to Kamasan in 1979 he took copies of the recently published museum catalogue. On the same visit he purchased a new version of the same painting by Mangku Mura. Mangku Mura had correctly identified the old painting as Jaratkaru from the Adiparwa (the first book of the Mahabharata). Jaratkaru is the name of a brahmana man whose failure to marry and reproduce condemns his parents to suffer in hell. The figure of Jaratkaru appears in the top right-hand corner of both paintings, talking to his mother and father who are hanging from a tree. To rescue them from this terrible fate, Jaratkaru must take a wife; he marries a woman of the same name, the daughter (or sister) of serpent-king Basuki (Zoetmulder 1974: 68-69). They have a son called Astika, who later saves the serpents from death in a sacrificial fire (yadnya) ordered by King Janamejaya to avenge the death of his father, killed by the serpent Taksaka.

The Jaratkaru story became something of a favourite for Mangku Mura. In addition to the initial version he produced after receiving the museum catalogue 
in 1979 , there are several other Jaratkaru paintings in circulation. ${ }^{8}$ One was made for the home of the late artist and is displayed during rites of passage (manusa yadnya), including the first birthday ceremony (oton) for the late artist's great-granddaughter pictured here (Figure 8). Officially held when a child is 210 days old (six Balinese months), the child ceremonially touches the ground for the first time and has her head shaved clean to remove the impurities of birth. ${ }^{9}$ The same offering platform was decorated with an ider-ider of the Bima Swarga story, mentioned above. In this setting the two narratives, with their shared iconography and narrative elements, complemented each other. Both had a direct bearing on the ceremony as the narratives make explicit reference to the responsibilities of children to their ancestors.

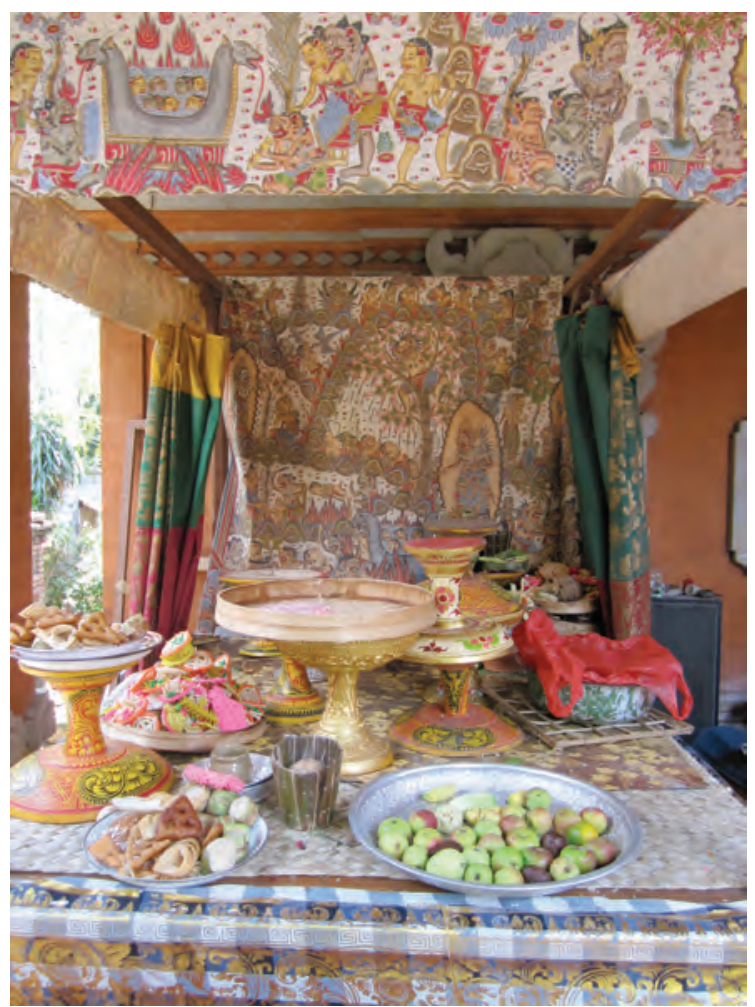

Figure 8. The Jaratkaru painting on the temple shrine in the family compound of Mangku Mura, Kamasan, 2011

Photo: Siobhan Campbell

8 One version, in a private collection in the United States is illustrated in T.M. Hunter (1988). Another version belonged to the collector Leo Haks and was sold through a Singapore auction house in 2011 (Borobodur Fine Art 2011).

9 At birth a child is considered a reincarnation of a purified ancestor and may not touch the ground or enter any temples until a ceremony is held to welcome the soul into the body. The first birthday ceremony (oton) cleans the impurities received at birth, partly from contact between the head and the genitalia of the mother on exiting the womb (Eisemen 1990: 84-95). 


\section{Conclusion}

The replication of the narrative tells us something of Balinese conventions regarding originality. By creating several new paintings from an old one, Mangku Mura demonstrated that artists maintain inventories of narrative and rework them time and time again, subjecting each version to individual variation. That is, each time a painting is produced, components of the story are reordered and rendered anew. Artists actively distinguish between the works of different artists; they single out personal embellishments and recognise the individual traits of particular artists. In one sense the art is conventional because artists work according to certain parameters and adhere to strict proscriptions in terms of iconography. They each interpret these stylistic boundaries in different ways, however, introducing innovations while maintaining that they belong to an unchanging tradition of great antiquity.

Mangku Mura's identification of the narrative painting of Jaratkaru serves as an example of the transformations prompted by Forge's collecting project. A momentarily forgotten narrative was reinstated and went on to function in multiple contexts: within Balinese ceremony and alongside other Balinese fine art in a Singapore auction house (see Borobodur Fine Art 2011). Mangku Mura's response to the Jaratkaru painting tells us that Kamasan art moves in and out of categories. It cannot be categorically described as entirely religious, fine art or tourist art, as many observers are wont to do. Rather, paintings communicate on different levels. When the Jaratkaru is part of a life cycle ceremony in a Balinese compound, it is linked to a set of ritual behaviours that contextualise it in terms of local meanings. As Howard Morphy (1992: 101) reminds us, paintings also 'have a meaning quite independent of their use in a particular ceremonial context'. Paintings can be 'specific' to a certain context and 'of more general significance' at the same time.

Many of the recollections related above refer to Forge's activities in Kamasan in the context of paintings becoming commodified objects. In these contexts paintings circulate in settings and in a manner that 'might well be regarded as deeply inappropriate in other contexts' (Appadurai 1986: 15). Engagement with collections in a contemporary context thus has a significance that goes beyond making assertions about indigenous agency within the collection. In this instance engagement with the creator community highlighted collecting in terms of exchange relations and the economic values it presented. While these responses have implications for more general understandings of the commodification of Balinese art, there is little doubt that Forge's written analysis of the village was secondary to his symbolic role as a patron and collector of art.

Beyond amusing recollections of the foreigner in their midst, the ways that people in Kamasan talked about and related to the Forge Collection suggest the potential for ongoing reassessment of the museum collection. The various anecdotes are just as much a comment on present interests and priorities as they are about earlier engagements with Forge and his collecting project. 
Gathering new perspectives on the collection reaffirms the sense that museum professionals and academics are not the sole authorities with respect to the knowledge contained in collections. The key message here is that collections are not ahistorical; museums can look to collected objects to track changes in communities over time. In doing so, museums embracing the spirit of community engagement are now challenged to reflect these changes in the museum collection.

Siobhan Campbell teaches in the Indonesian Studies program at the University of Sydney. She completed her PhD thesis on the Forge Collection of Balinese Paintings at the Australian Museum in Sydney in 2013.

\section{References}

Appadurai, Arjun 1986, 'Introduction: Commodities and the politics of value', in Arjun Appadurai (ed.), The Social Life of Things: Commodities in Cultural Perspective, Cambridge University Press.

Bali Post, 2010, 'Empat Komplotan Putu Oka Dibekuk', 19 September, viewed 4 May 2011, http://www.balipost.co.id/mediadetail.php?module=detailberit a\&kid=2\&id=42019.

Borobudur Fine Art 2011, Pre-War Balinese Modernist Paintings; the Collection of Leo Haks, Singapore: Borobudur Fine Art Auction.

Campbell, Siobhan 2014, 'Anthony Forge in Bali: The making of a museum collection,' Visual Anthropology, vol. 27, no. 3, pp. 248-75.

Causey, Andrew 2003, Hard Bargaining in Sumatra: Western Travelers and Toba Bataks in the Marketplace of Souvenirs, Honolulu: University of Hawai'i Press.

Cooper, Thomas L. 1997, 'The values of Bagus Diarsa', Indonesia and the Malay World, vol. 25, no. 71, pp. 22-49.

- - (2005), Sacred Painting in Bali: Tradition in Transition, Bangkok: Orchid Press.

Covarrubias, Miguel (1937 (reprinted 1972)), Island of Bali, Kuala Lumpur: Oxford University Press.

Dudding, Jocelyne 2005, 'Visual repatriation and photo-elicitation: Recommendations on principles and practices for the museum worker', Journal of Museum Ethnography, vol. 17, pp. 218-31.

Eiseman, Jr., Fred B. 1990, Bali: Sekala and Niskala; Volume l: Essays on Religion, Ritual, and Art, Singapore: Periplus. 
Forge, Anthony 1966, 'Art and environment in the Sepik', Proceedings of the Royal Anthropological Institute for 1965, London: Royal Anthropological Institute, pp. 23-31.

- - 1973, 'Style and meaning in Sepik art', in Anthony Forge (ed.), Primitive Art \& Society, London; New York: Oxford University Press.

- - 1978, Balinese Traditional Paintings: A Selection from the Forge Collection of the Australian Museum, Sydney: Australian Museum.

- - 1980, 'Balinese religion and Indonesian identity', in James Fox (ed.), Indonesia: The Making of a Culture, Canberra: Research School of Pacific Studies, The Australian National University.

Forshee, Jill 2001, Between the Folds: Stories of Cloth, Lives, and Travels from Sumba, Honolulu: University of Hawai'i Press.

Geertz, Hildred 1994, Images of Power: Balinese Paintings Made for Gregory Bateson and Margaret Mead, Honolulu: University of Hawai'i Press.

- - 2004, The Life of a Balinese Temple: Artistry, Imagination, and History in a Peasant Village, Honolulu: University of Hawai'i Press.

Geismar, Haidy 2009, 'Photographs and foundations: Visualising the past on Atchin and Vao', in Haidy Geismar \& Anita Herle (eds), Moving Images: John Layard, Fieldwork and Photography on Malakula since 1914, Belair: Crawford House in association with the CUMAA.

Geismar, Haidy \& Herle, Anita (eds) 2009, Moving Images: John Layard, Fieldwork and Photography on Malakula since 1914, Belair: Crawford House in association with the CUMAA.

Hauser-Schäublin, Brigitta 2012, 'The diversion of the village gods: A criminal turn in the biography of Balinese copperplate inscriptions', Bijdragen tot de Taal-, Land- en Volkenkunde, vol. 168, no. 1, pp. 74-99.

Harrison, Rodney, Byrne, Sarah \& Clarke, Anne (eds) 2013, Reassembling the Collection: Ethnographic Museums and Indigenous Agency, Santa Fe, NM: SAR Press.

Hunter, T.M. 1988, 'Crime and punishment in Bali: Paintings from a Balinese hall of justice', Review of Indonesian and Malaysian Affairs, vol. 22, no. 2, pp. 62-113.

MacRae, Graeme 2010, 'If Indonesia is too hard to understand, let's start with Bali', Journal of Indonesian Social Sciences and Humanities, vol. 3, pp. 11-36. 
McGowan, Kaja 2008, 'Raw ingredients and deposit boxes in Balinese sanctuaries: A congruence of obsessions', in Jan Mrazek \& Morgan Pitelka (eds), What's the Use of Art?: Asian Visual and Material Culture in Context, Honolulu: University of Hawai'i Press.

Morphy, Howard 1992, Ancestral Connections, University of Chicago Press.

Myers, Fred R. 2002, Painting Culture: The Making of an Aboriginal High Art, Durham: Duke University Press.

Peers, Laura L. \& Brown, Alison K. 2003, Museums and Source Communities: A Routledge Reader, London; New York: Routledge.

Schulte Nordholt, Henk 2007, Bali: An Open Fortress, 1995-2005: Regional Autonomy, Electoral Democracy and Entrenched Identities, Singapore: NUS Press.

The Jakarta Globe, 2010, 'Dozens of Stolen Artifacts Recovered in Bali', 8 September, viewed 4 May 2011, http://www.thejakartaglobe.com/home/ dozens-of-stolen-artifacts-recovered-in-bali/395162.

Vickers, Adrian 1987, 'Hinduism and Islam in Indonesia: Bali and the Pasisir world', Indonesia, vol. 44, pp. 31-58.

- - 2005, Journeys of Desire: A Study of the Balinese Text Malat, Leiden: KITLV Press.

- - 2012, Balinese Art: Paintings and Drawings of Bali 1800-2012, Singapore: Tuttle.

Zoetmulder, P.J. 1974, Kalangwan: A Survey of Old Javanese Literature, The Hague: Martinus Nijhoff. 
This text taken from craft + design enquiry issue 6, 2014, Craft.Material. Memory, Edited by Anne Brennan and Patsy Hely, published 2014 by ANU Press, The Australian National University,

Canberra, Australia. 